\title{
Perbandingan Nilai Ukur Sensor Load Cell pada Alat Penyortir Buah Otomatis terhadap Timbangan Manual
}

\author{
WAHYUDI, ABDUR RAHMAN, MUHAMMAD NAWAWI \\ Program Studi Sarjana Terapan Teknik Elektro, Jurusan Teknik Elektro, \\ Politeknik Negeri Sriwijaya \\ Email : Wahyudijamistry@gmail.com
}

\begin{abstract}
ABSTRAK
Nilai ukur antara sensor load cell yang ada pada timbangan digital dan nilai ukur pada timbangan konvensional atau manual terkadang memiliki perbedaan yang sangat signifikan diantara keduanya, hal ini biasanya diakibatkan oleh beberapa faktor yang mempengaruhi perbedaan nilai ukur tersebut, oleh karena itu pada penelitian kali ini, akan dilakukan suatu pengukuran dan pengujian berat suatu beban dengan objek yang ukur yaitu buah apel, tomat dan jeruk. Pengujian ini dilakukan untuk mengetahui sistem mana yang lebih efisien dan akurat dalam melakukan suatu perhitungan berat suatu buah. Untuk tahap pertama, Proses pengukuran berat buah menggunakan sensor load cell dilakukan pada alat penyortir buah otomatis, kemudian untuk tahap kedua, pengukuran buah dilakukan dengan menggunakan timbangan jenis manual atau konvensioanal. Setelah didapat nilai perhitungan dari keduanya, selanjutnya akan dianalisa dan dibandingakan hasil ukur dari kedua sistem tersebut untuk mengetahui tingkat efisiensi dari keduanya.
\end{abstract}

Kata Kunci : Perbandingan, Nilai Ukur, Load Cell, Timbangan Manual, keakuratan

\begin{abstract}
The measuring values between the load cell sensors present in the digital scales and the measured values on the conventional or manual scales sometimes have a very significant difference between them, this is usually due to several factors affecting the difference in measuring values, therefore in this study, Will be done a measurement and testing the weight of a load with the measuring object of apples, tomatoes and oranges. This test is conducted to determine which system is more efficient and accurate in performing a weight calculation of a fruit. For the first stage, the process of measuring the weight of fruit using the load cell sensor is done on the automatic fruit sorter, then for the second stage, the fruit measurement is done by using manual or conventional scales. Having obtained the value of the calculation of both, then will be analyzed and compared the results of measuring both systems to determine the level of efficiency of both.
\end{abstract}

Keywords: Comparison, Measure Value, Load Cell, Manual Scales, Accuracy 


\section{PENDAHULUAN}

Pemakaian timbangan jenis konvensional atau manual lebih sering kita jumpai dalam kehidupan sehari-hari daripada timbangan digital. Walaupun Penggunaan timbangan digital lebih praktis karena terdapat jantung atau komponen utama dari skala pengukurannya yaitu Load Cell (Thakkar, dkk, 2013). Namun penggunaan timbangan jenis konvensional masih tetap mendominasi di dalam kehidupan masyarakat. Fungsi dari kedua jenis timbangan ini adalah sama, yaitu untuk menghitung berat suatu benda, masing-masing dari kedua jenis timbangan ini memiliki karakteristik dan tingkat akurasi pengukuran yang berbeda (Erlangga, 2011). Dan terkadang hasil pengukuran berat suatu benda yang bersifat manual ataupun digital sering terjadi kesalahan (error) bahkan tidak akurat dan efisien, hal ini tentu akan merugikan banyak pihak, penyebab ketidakakuratan ini bisa disebabkan oleh beberapa faktor seperti kondisi mekanik dari alat ukur itu sendiri maupun dari manusianya. Berbeda dengan timbangan manual, di sisi lain timbangan digital yang dibuat lebih praktis karena dapat merekam dan menyimpan data langsung ke komputer tanpa harus melakukan pencatatan secara manual ( Kamirul, dkk, 2015 ). Perlu kita ketahui juga Penggunaan alat pengukuran digital dalam kehidupan sehari-hari sangat membantu memudahkan kinerja manusia (Afdali, dkk, 2017).

Upaya pembuatan timbangan digital telah banyak dilakukan oleh beberapa peneliti salah satunya hidayani (Hidayani, dkk, 2013) yang merancang alat timbangan digital dengan output yang dihasilkan yaitu berat dan harga. Kemudian Erlangga (Erlangga, 2011) juga mengembangkan suatu rancang bangun alat timbangan jenis digital dengan output memilih berbagai jenis buah. Selanjutnya Thakkar dkk (Thakkar, dkk, 2013) juga membuat sebuah penelitian tentang permasalahan pada load cell dan peningkatan sistem ketelitian dalam penimbangan pada sensor load cell. Namun dari sekian banyak rancang bangun alat di atas dan dari berbagai jenis penelitian-penelitian tersebut hanya menyajikan hasil ukur berat benda dari timbangan digital saja serta sistem penimbangan dari timbangan digital saja, padahal kita juga bisa menyajikan hasil pengukuran dari timbangan manual atau konvensional agar bisa kita ketahui timbangan jenis mana yang lebih efisien dan akurat dalam melakukan pengukuran berat suatu benda atau objek.

Maka dari itu, pada penelitian kali ini dilakukan uji coba pengukuran dan pengujian sensor load cell yang ada pada alat penyortir buah otomatis dan juga timbangan manual, dengan tujuan untuk mengetahui tingkat akurasi dan sistem error pengukuran dari kedua alat tersebut, agar bisa ditarik kesimpulan dan dipersentasekan tingkat keakuratan pengukuran dari keduanya.

\subsection{Timbangan}

Timbangan adalah suatu alat yang bisa dipakai untuk melakukan uji coba pengukuran berat dari suatu benda. sedangkan Menurut Latifah (Latifa, 2014) timbangan bisa di artikan sebagai sebuah alat yang bisa dipakai untuk melakukan pengukuran berat dari suatu benda. Terdapat dua sistem kategori dalam timbangan yaitu timbangan dengan sistem mekanik/analog dan sistem elektronik/digital (Khakim, 2015). Timbangan manual, yaitu jenis timbangan biasa yang bekerja secara manual melalui perantara manusia yang sering digunakan dalam kehidupan sehari-hari. sedangkan Timbangan digital, yaitu jenis timbangan yang dapat bekerja secara elektronik dan otomatis dengan input arus listrik dan indikatornya berupa angka digital yang ditunjukkan pada layar LCD. Berikut ini merupakan Persamaan matematis suatu neraca pegas pada timbangan manual dinyatakan dalam: 


$$
k \cdot \mathrm{X}=\mathrm{m} \cdot \mathrm{g}
$$

Dimana $k$ adalah konstanta pegas, $\mathrm{X}$ adalah defleksi, $\mathrm{m}$ adalah massa, dan $\mathrm{g}$ adalah gravitasi

\subsection{Sensor Load Cell}

Load Cell merupakan komponen inti yang terdapat pada timbangan digital. Secara umum load cell digunakan untuk menghitung massa dari suatu benda. Sebuah sensor load cell tersusun dari beberapa konduktor, strain gauge, dan jembatan wheatstone (Nuryanto, 2015). sensor Load cell yang dipakai dalam penelitian tugas akhir ini memiliki kapasitas berat maksimum $8 \mathrm{~kg}$. Tetapi dalam perancangan penelitian kali ini dibuat beban pengukuran maksimal $5 \mathrm{~kg}$.

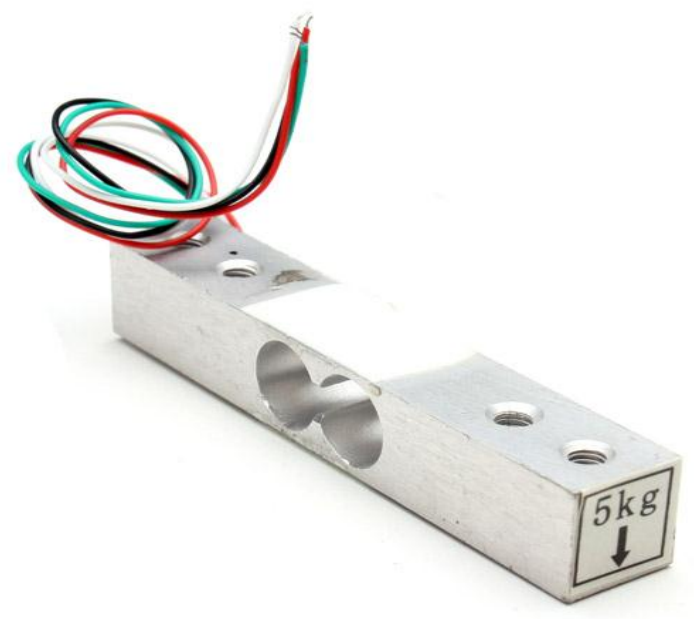

Gambar 1. Sensor Load Cell

\subsection{Jembatan Weatstone}

Jembatan wheatstone digunakan sebagai pengkondisi sinyal yang di hasilkan oleh sensor load cell. Berikut gambar jembatan wheatstone:

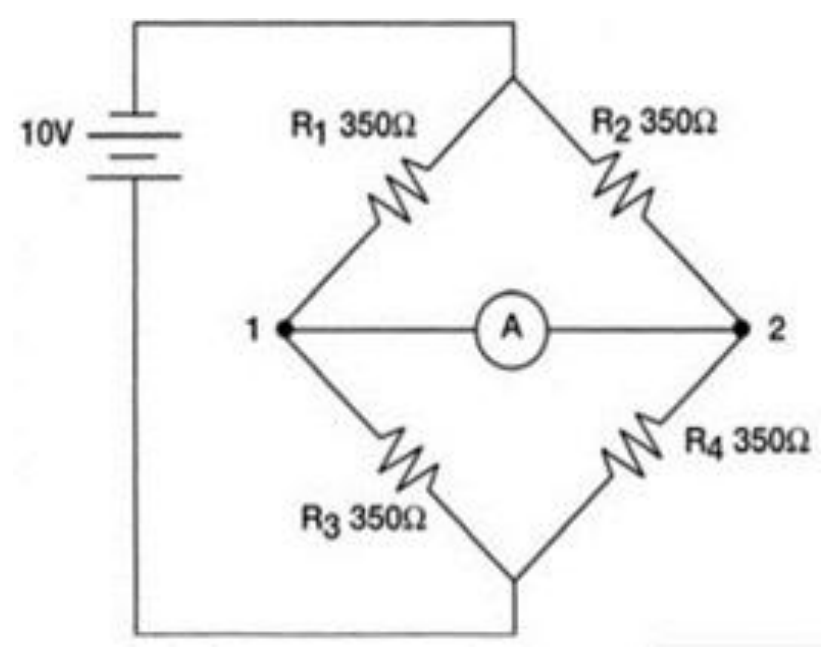

Gambar 2. Titik seimbang Jembatan Weatstone 


\subsection{Modul Amplifier HX711}

Modul HX711 merupakan modul amplifier yang biasa digunakan dalam rangkaian timbangan digital sebagai modul konversi sinyal analog ke digital pada load cell. Memiliki presisi tinggi 24 ADC high gain input yang didesain untuk berbagai sensor berjenis Bridge. Dengan dua channel A dan B (fix gain 32) yang berkomunikasi secara multiplex, modul ini dapat di program untuk gain 128 atau $64(20 \mathrm{mV}$ atau $40 \mathrm{mV}$ ). Prinsip kerja dari modul HX711 ini yaitu sebagai penguat tegangan pada load cell pada saat load cell bekerja. HX711 presisi 24-bit analog to digital converter (ADC) (Khakim, 2015)

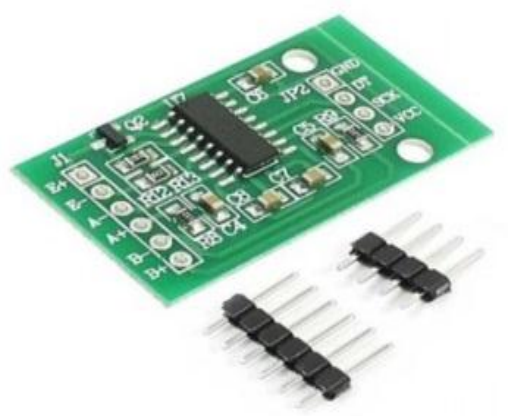

Gambar 3. Modul HX711

\subsection{LCD 16x2 Sebagai Penampil Karakter}

Liquid Crystal Display merupakan papan penampil berupa karakter, tulisan, huruf dan angka berjenis elektronik. Prinsip kerja LCD ini yaitu dapat menangkap dan memantulkan cahaya yang ada disekelilingnya terhadap front-lit atau mentransmisikan cahaya dari back-lit. Pada penelitan kali ini LCD yang dipakai yaitu jenis LCD 16×2 Seperti ditunjukkan pada Gambar 4.

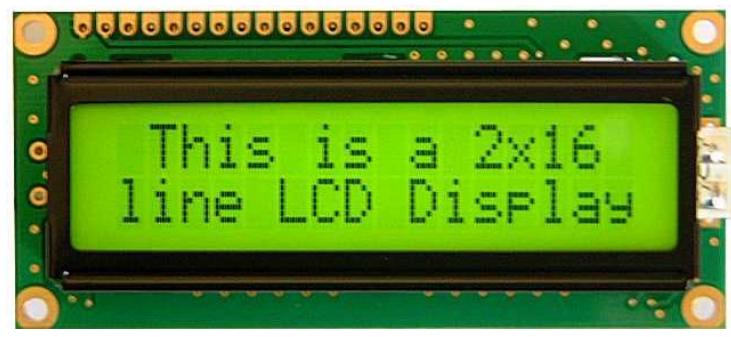

Gambar 4. Lcd 16x2

\subsection{Arduino}

Arduino merupakan perangkat keras (hadware) papan mikrokontroler tunggal open source. Di dalam arduino tersebut terdapat sebuah chip mikrokontroler dengan tipe AVR sebagai komponen utama yang dikeluarkan oleh perusahaan Atmel. Mikrokontroler itu sendiri adalah chip atau integrated circuit (IC) yang bisa diprogram menggunakan komputer (Utama, dkk, 2008). Pada penelitian kali ini jenis Arduino yang digunakan yaitu Arduino Mega, Seperti ditunjukkan oleh Gambar 5. 


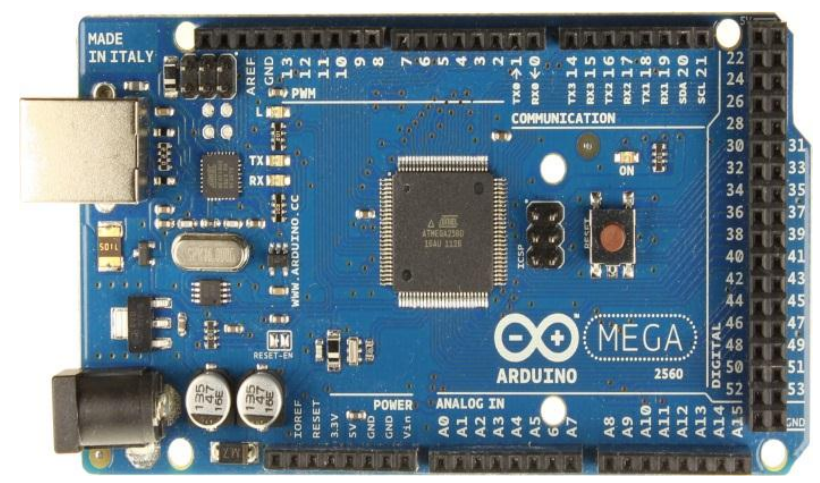

\section{Gambar 5. Arduino Mega}

\subsection{Motor Servo}

Motor servo merupakan motor yang diatur dan dikontrol menggunakan pulsa. Motor standar ini memiliki tiga posisi yaitu posisi 0 derajat, posisi 90 derajat, dan posisi 180 derajat. Poros motor servo biasanya dihubungkan dengan suatu mekanisme sehingga dapat membuat atau mengontrol pergerakan roda depan pada sebuah mobil mainan. Pada saat poros pada posisi 0 derajat, maka roda mobil mainan akan bergerak kekiri, jika posisi poros pada 90 derajat, maka roda depan mobil maianan akan lurus, sedangkan jika posisi 180 derajat, maka roda depan mobil akan berbelok kekanan.
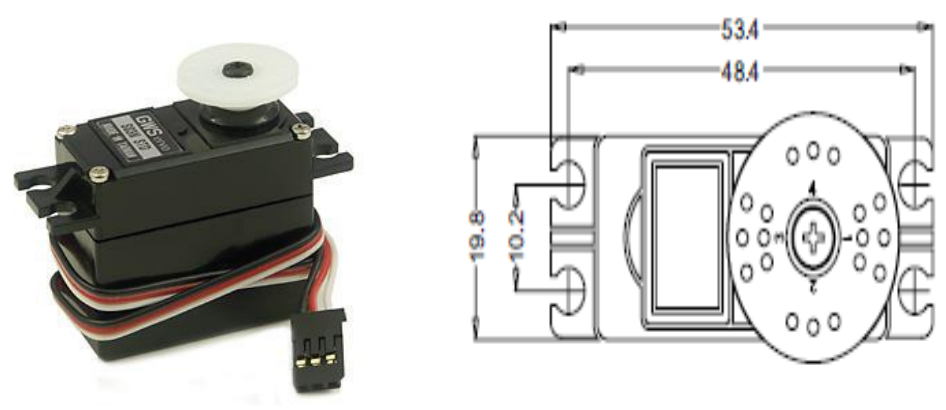

Gambar 6. Motor Servo

\section{METODOLOGI PENELITIAN}

Pada penelitian ini membahas tentang perbandingan nilai ukur sensor load cell pada alat penyortir buah otomatis terhadap timbangan manual atau konvensional, disertai dengan analisa kualifikasi perbandingan nilai perhitungan dari kedua sistem tersebut untuk diambil kesimpulan tingkat akurasi dan sistem error dari keduanya dan ditetapkan alat mana yang lebih akurat dan efisien dalam melakukan pengukuran berat benda. Disertakan juga sebuah Perancangan sistem timbangan digital pada alat penyortir buah otomatis yang meliputi perancangan perangkat keras atau hardware dan perangkat lunak atau software.

\subsection{Blok Diagram Sistem}

Blok diagram adalah suatu bagian dari prinsip dan kinerja suatu sistem dalam membuat suatu perancangan alat. Cara kerja keseluruhan sebuah alat yang akan dibuat terletak pada blok diagram system. Berikut ini merupakan gambar blok diagram dari sistem kerja pengukuran sensor load cell dan proses perhitungannya pada alat penyortir buah otomatis berbasis mikrokontroler arduino mega. 


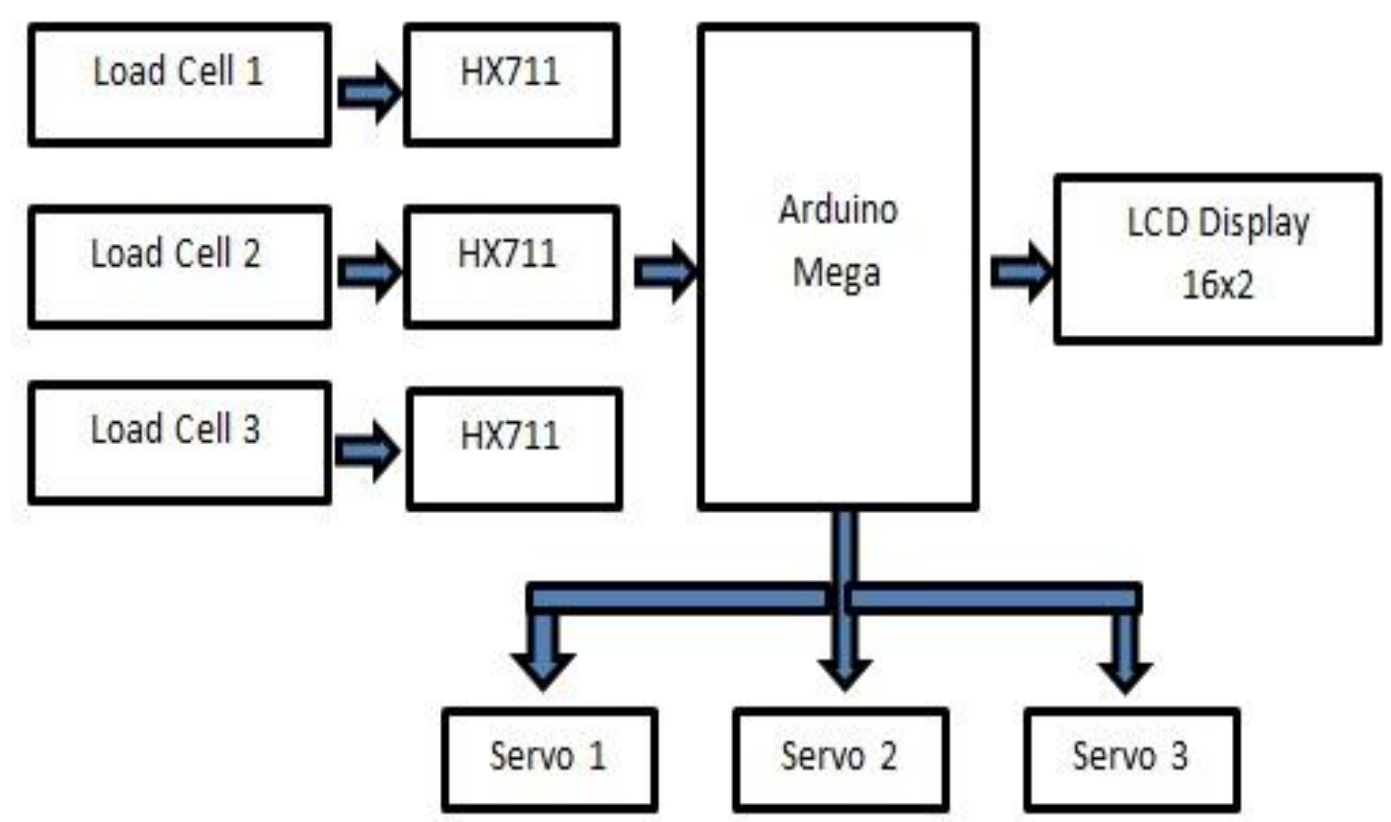

\section{Gambar 7. Blok Diagram Sistem Kerja Load cell pada alat penyortir buah otomatis}

Berdasakan penjelasan dari blok diagram pada gambar 7 di atas blok sensor load cell Sebagai inputan pendeteksi berat buah yang akan diukur, Blok Amplifier HX711, Sebagai inputan penguat sensor load cell, Blok Mikrokontroler Arduino, sebagai unit pemroses dan pengontrol seluruh sistem alat. Blok LCD, sebagai penampil hasil pengukuran buah, Blok Servo Controller, sebagai pengendali motor servo yang digunakan pada bagian kotak penimbang buah.

\section{$2.2 \quad$ Flowchart}

Flowchart adalah adalah alur kerja dari suatu proses terhadap sistem yang telah dibuat agar dapat dengan mudah untuk dipahami dan dijelaskan dengan simbol-simbol tertentu yang menggambarkan urutan proses secara mendetail dan hubungan antara suatu proses (instruksi) dengan proses lainnya dalam suatu program. Gambar 8 Berikut merupakan Flowchart sistem kerja sensor load cell sebagai pendeteksi berat buah pada alat penyortir buah otomatis. 


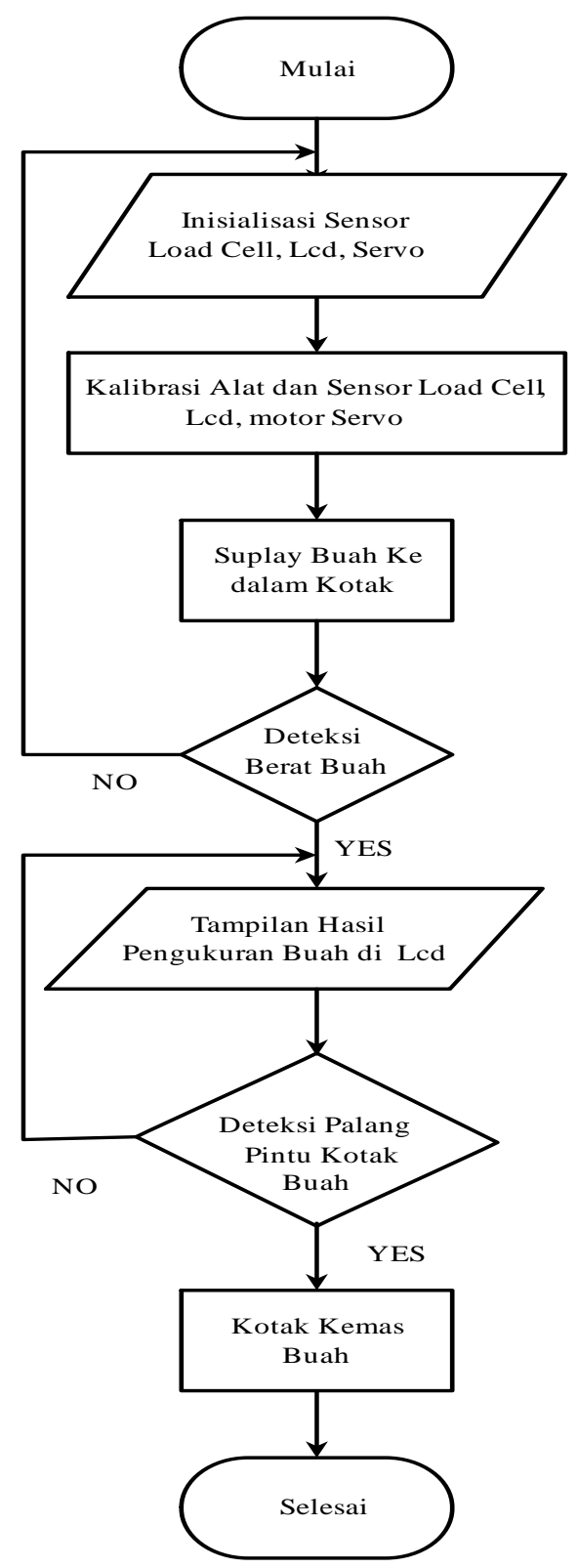

Gambar 8. Flowchart Sistem Kerja Load Cell pada Alat Penyortir Buah Otomatis

\subsection{Sistem Perancangan Mekanis Alat}

Pada sistem perancangan mekanis ini yang akan dilakukan yaitu Pengumpulan komponenkomponen yang akan digunakan untuk membuat suatu sistem pengukuran sensor load cell atau timbangan digital pada alat penyortir buah otomatis. Pada tahap ini digunakan datasheet serta petunjuk lain yang dapat membantu dalam mengetahui spesifikasi dari komponen yang akan di gunakan, sehingga komponen yang didapat tersebut merupakan pilihan yang tepat bagi alat atau sistem yang akan dibuat. selanjutnya Merancang bentuk sistem timbangan digital pada alat penyortir buah otomatis dan mendesain sebagus mungkin dengan ukuran-ukuran yang sesuai agar tidak mengganggu sistem kerja alat nantinya. Spesifikasi dan rangka timbangan digital pada alat Penyortir buah otomatis ditunjukkan pada Gambar 9 berikut ini. 


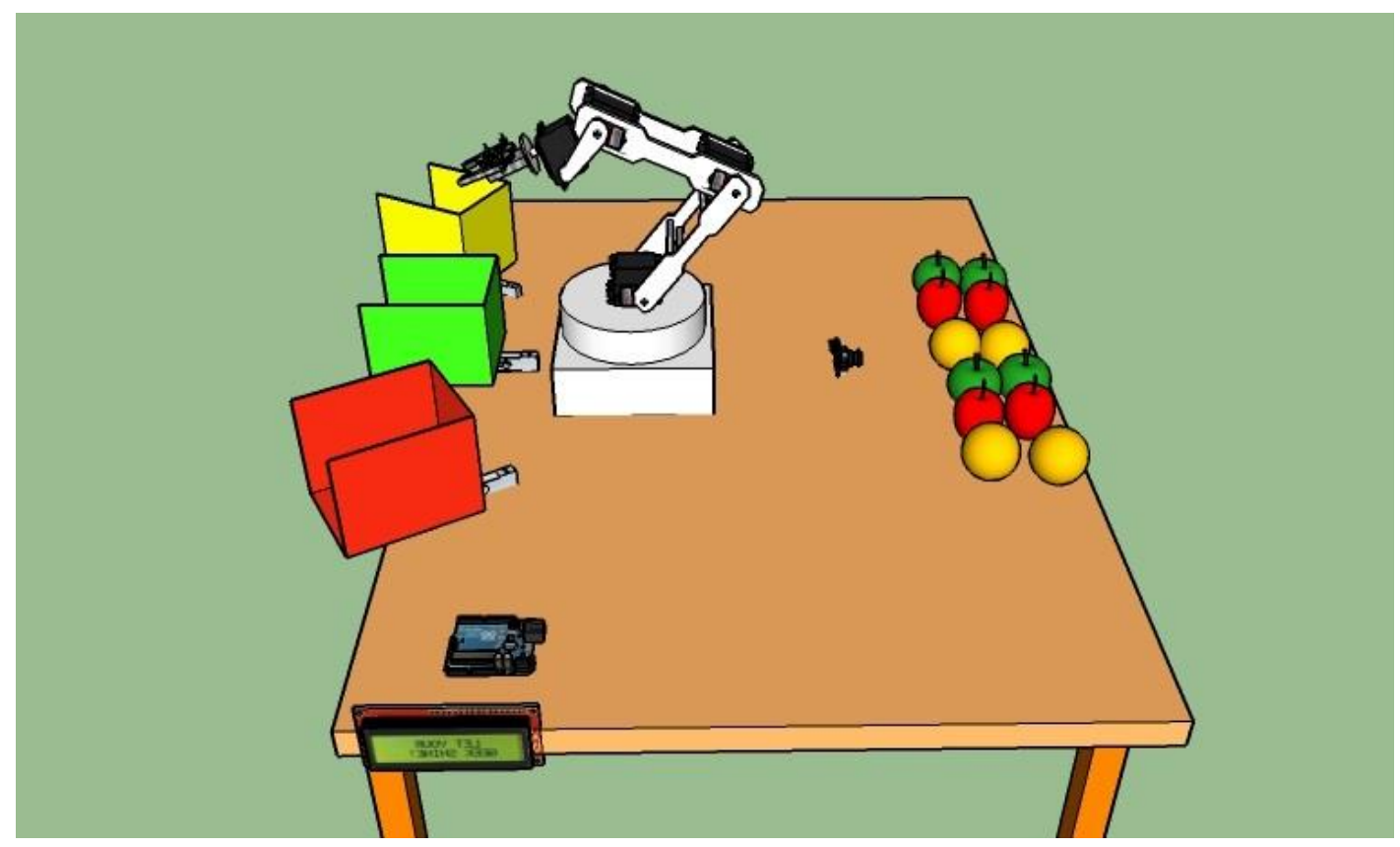

Gambar 9. Rancangan mekanik alat penyortir buah otomatis

\subsection{Skematik Rangkaian Sensor Load Cell Pendeteksi Berat Buah}

Perancangan timbangan digital pada alat penyortir buah otomatis ini akan di gambarkan dalam sebuah rangkaian skematik, rangkaian skematik ini merupakan gabungan antara sensor load cell, HX711, LCD, Motor Servo dan Arduino mega. Rangkaian skematik ini merupakan suatu metode analisis sistem kerja komponen elektronika yang digunakan. dibuat agar dapat lebih mudah unutk memahami tata letak komponen serta hubungan antara satu komponen dengan komponen yang lainnya. Gambar 10 merupakan rangkaian skematik dan layout pendeteksi berat buah menggunakan sensor load cell pada alat penyortir buah otomatis.

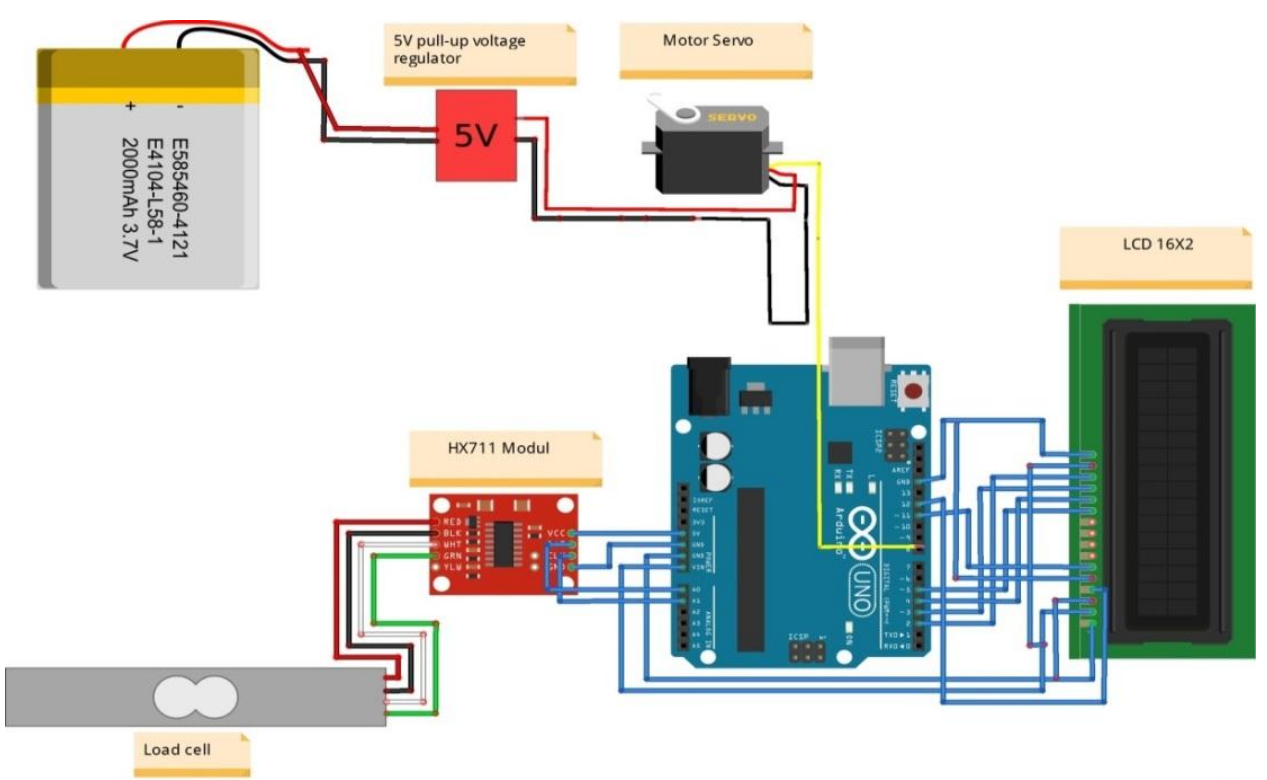

Gambar 10. Rancangan Skematik sistem pengukuran menggunakan Load Cell 


\subsection{Pengujian Ketelitian alat}

Untuk mengetahui ketelitian pengujian suatu alat diperlukan sebuah metode perhitungan khusus untuk mengetahuinya. Berikut ini telah dibuat metode perhitungan pengujian ketelitian alat yang telah direalisasikan. Setelah diperoleh data dari hasil pengujian dan pengukuran berat buah oleh sensor load cell dan timbangan konvensioanl, maka langkah selanjutnya adalah menganalisa data tersebut untuk dilakukan perhitungan analisis nilai persentase (\%) keberhasilan dan nilai persentase (\%) kesalahan (error). Rumus-rumus untuk menghitung dan mencari persentase kesalahan dan keberhasilan pengukuran sensor load cell maupun timbangan konvensional adalah berdasarkan Persamaan $2-6$ berikut ini (Paleri, 2015).

Persentase rata-rata hasil pengukuran Load Cell $=\frac{S 1+S 2+S 3}{3}$

Persentase kesalahan pengukuran pada Load Cell $=\frac{S-X}{S} \times 100 \%$

Persenstase Keberhasilan Pengukuran Load Cell $=\frac{X}{S} \times 100 \%$

Persentase kesalahan pengukuran pada Timbangan Manual $=\frac{X-S}{S} \times 100 \%$

Persenstase Keberhasilan Pengukuran Timbangan Manual $=\frac{S}{X} \times 100 \%$

Dimana $S 1, S 2$ dan $S 3$ adalah jumlah pengukuran dan pengujian, $S$ adalah nilai hasil ukur load cel/ dan timbangan manual dan $x$ adalah nilai range atau batasan kapasitas pengukuran

\section{HASIL PENGUJIAN DAN PEMBAHASAN}

\subsection{Pengujian Sensor Load Cell Peneteksi Berat Buah}

Pengujian sistem pendeteksian berat buah menggunakan sensor load cell ini dilakukan dengan cara memasukan buah ke dalam kotak timbang yang dibawahnya telah diberi sensor load cell. terdapat tiga buah kotak timbang yang masing-masing telah diberi sensor load cell, pada kotak timbang 1 kapasitas pengkuran 3,5 Kg, kotak timbang 2 kapasitas pengukuran $2,5 \mathrm{Kg}$ dan kotak timbang yang 3 kapasitas pengukurannya $4,0 \mathrm{~kg}$. Selanjutnya, setelah berat buah diukur oleh sensor load cell, LCD akan langsung menerima perintah untuk menampilkan hasil ukur sensor load cell tersebut. Hasil pengujian dan perhitungan terebut ditunjukkan pada Tabel 1, 2, dan 3 di bawah ini.

Tabel 1. Hasil Pengujian dan Pengukuran Berat Buah Pada Kotak 1

\begin{tabular}{|c|c|c|c|c|c|c|c|c|}
\hline \multirow[t]{2}{*}{ No } & \multirow{2}{*}{$\begin{array}{c}\text { Nama } \\
\text { Buah }\end{array}$} & \multirow{2}{*}{$\begin{array}{l}\text { Range } \\
\text { (Kg) }\end{array}$} & \multirow{2}{*}{$\begin{array}{c}\text { Hasil } 1 \\
(\mathbf{K g})\end{array}$} & \multirow{2}{*}{$\begin{array}{c}\text { Hasil } 2 \\
(\mathbf{K g})\end{array}$} & \multirow{2}{*}{$\begin{array}{c}\text { Hasil } 3 \\
(\mathbf{K g})\end{array}$} & \multicolumn{2}{|c|}{$\begin{array}{c}\text { Rata-rata } \\
\text { Keberhasilan }\end{array}$} & \multirow{2}{*}{$\begin{array}{c}\text { Error } \\
(\%)\end{array}$} \\
\hline & & & & & & (Kg) & $(\%)$ & \\
\hline 1 & Apel & 3,5 & 3,7 & 3,6 & 3,5 & 3,6 & 97,23 & 2,77 \\
\hline 2 & Jeruk & 3,5 & 3,5 & 3,6 & 3,5 & 3,5 & 100 & 0 \\
\hline 3 & Tomat & 3,5 & 3,8 & 3,5 & 3,5 & 3,6 & 97,23 & 2,77 \\
\hline
\end{tabular}


Tabel 2. Hasil Pengujian dan Pengukuran Berat Buah Pada Kotak 2

\begin{tabular}{|c|c|c|c|c|c|c|c|c|}
\hline No & $\begin{array}{c}\text { Nama } \\
\text { Buah }\end{array}$ & $\begin{array}{c}\text { Range } \\
\mathbf{( K g )}\end{array}$ & $\begin{array}{c}\text { Hasil 1 } \\
\mathbf{( K g )}\end{array}$ & $\begin{array}{c}\text { Hasil 2 } \\
\mathbf{( K g )}\end{array}$ & \multirow{2}{*}{$\begin{array}{c}\text { Hasil 3 } \\
\mathbf{( K g )}\end{array}$} & \multicolumn{2}{|c|}{$\begin{array}{c}\text { Rata-rata } \\
\text { Keberhasilan }\end{array}$} & $\begin{array}{c}\text { Error } \\
\mathbf{( \% )}\end{array}$ \\
\hline 1 & Apel & 2,5 & 2,7 & 2,6 & 2,5 & 2,6 & 96,15 & 3,85 \\
\hline 2 & Jeruk & 2,5 & 2,6 & 2,6 & 2,7 & 2,6 & 96,15 & 3,85 \\
\hline 3 & Tomat & 2,5 & 2,5 & 2,6 & 2,4 & 2,5 & 100 & 0 \\
\hline
\end{tabular}

Tabel 3. Hasil Pengujian dan Pengukuran Berat Buah Pada Kotak 3

\begin{tabular}{|c|c|c|c|c|c|c|c|c|}
\hline \multirow[t]{2}{*}{ No } & \multirow{2}{*}{$\begin{array}{l}\text { Nama } \\
\text { Buah }\end{array}$} & \multirow{2}{*}{$\begin{array}{c}\text { Range } \\
(\mathbf{K g})\end{array}$} & \multirow{2}{*}{$\begin{array}{c}\text { Hasil } 1 \\
(\mathbf{K g})\end{array}$} & \multirow{2}{*}{$\begin{array}{c}\text { Hasil } 2 \\
(\mathbf{K g})\end{array}$} & \multirow{2}{*}{$\begin{array}{c}\text { Hasil } 3 \\
\text { (Kg) }\end{array}$} & \multicolumn{2}{|c|}{$\begin{array}{c}\text { Rata-rata } \\
\text { Keberhasilan }\end{array}$} & \multirow{2}{*}{$\begin{array}{l}\text { Errol } \\
(\%)\end{array}$} \\
\hline & & & & & & $(\mathrm{Kg})$ & $(\%)$ & \\
\hline 1 & Apel & 4,0 & 4,2 & 4,1 & 4,1 & 4,1 & 97,56 & 2,44 \\
\hline 2 & Jeruk & 4,0 & 4,1 & 4,0 & 4,1 & 4,0 & 100 & 0 \\
\hline 3 & Tomat & 4,0 & 4,3 & 4,2 & 4,2 & 4,2 & 95,24 & 4,76 \\
\hline
\end{tabular}

Tabel 4. Hasil Keseluruhan Pengujian dan Pengukuran Berat Buah

\begin{tabular}{|c|c|c|c|c|c|c|c|c|}
\hline No & $\begin{array}{c}\text { Nama } \\
\text { Buah }\end{array}$ & $\begin{array}{c}\text { Jumlah } \\
\text { Range } \\
\mathbf{( K g )}\end{array}$ & $\begin{array}{c}\text { Hasil Ukur } \\
\text { Rata-rata } \\
\text { kotak 1 } \\
\mathbf{( K g )}\end{array}$ & $\begin{array}{c}\text { Hasil Ukur } \\
\text { Rata-rata } \\
\text { kotak 2 } \\
\mathbf{( K g )}\end{array}$ & $\begin{array}{c}\text { Hasil Ukur } \\
\text { Rata-rata } \\
\text { kotak 3 } \\
\mathbf{( K g )}\end{array}$ & $\begin{array}{c}\text { Jumlah } \\
\text { rata- } \\
\text { rata } \\
\mathbf{( K g )}\end{array}$ & $\begin{array}{c}\text { Sukses } \\
\mathbf{( \% )}\end{array}$ & $\begin{array}{c}\text { Error } \\
\mathbf{( \% )}\end{array}$ \\
\hline 1 & Apel & 10,0 & 3,6 & 2,6 & 4,1 & 10,3 & 97,09 & 2,91 \\
\hline 2 & Jeruk & 10,0 & 3,5 & 2,6 & 4,0 & 10,1 & 99,00 & 1,00 \\
\hline 3 & Tomat & 10,0 & 3,6 & 2,5 & 4,2 & 10,3 & 97,09 & 2,91 \\
\hline
\end{tabular}

Dari Tabel 4 diatas ditampilkan hasil keseluruhan pengujian dan pengukuran berat buah menggunakan sensor load cell dimana data pertama buah apel dengan kapasitas pengukuran $10 \mathrm{~kg}$ yang di dapat dari jumlah keseluruhan kapasitas pengukuran kotak timbang pertama $3,5 \mathrm{~kg}$, kotak timbang kedua $2,5 \mathrm{~kg}$ dan kotak timbang ketiga $5 \mathrm{~kg}$, nilai hasil ukur rata-rata kotak pertama $3,6 \mathrm{~kg}$, kotak kedua 2,6 kg dan kotak ketiga 4,6. Jadi pengukuran dan perhitungannya adalah sebagai berikut :

Jumlah ukur rata-rata $=S 1+S 2+S 3=3.6+2.6+4.1=10.3 \mathrm{~kg}$

Rata-rata keberhasilan $=\frac{X}{S} \times 100=\frac{10}{10.3} \times 100=97.09 \%$ 
Rata-rata kesalahan $=\frac{S-X}{S} \times 100=\frac{10.3-10}{10.3} \times 100=2.91 \%$

Berdasarkan hasil dan jumlah keseluruhan rata-rata yang didapatkan pada pengukuran dan pengujian berat buah menggunakan sensor load cell, maka diperoleh data seperti pada Tabel 5 di bawah ini :

Tabel 5. Rata -rata Keberhasilan dan tingkat error pengukuran pada sensor load cell

\begin{tabular}{|c|c|c|c|c|c|}
\hline $\begin{array}{c}\mathbf{N} \\
\mathbf{0}\end{array}$ & $\begin{array}{c}\text { Nama } \\
\text { Buah }\end{array}$ & $\begin{array}{c}\text { Jumlah } \\
\text { Range } \\
\mathbf{( K g )}\end{array}$ & $\begin{array}{c}\text { Hasil Ukur } \\
\text { Load Cell } \\
\mathbf{( K g )}\end{array}$ & $\begin{array}{c}\text { Keberhasilan } \\
\text { Pengukuran } \\
\mathbf{( \% )}\end{array}$ & $\begin{array}{c}\text { Kesalahan } \\
\text { Pengukuran } \\
\mathbf{( \% )}\end{array}$ \\
\hline 1 & Apel & 10,0 & 10,3 & $97,09 \%$ & $2,91 \%$ \\
\hline 2 & Jeruk & 10,0 & 10,1 & $99,00 \%$ & $1,00 \%$ \\
\hline 3 & Tomat & 10,0 & 10,3 & $97,09 \%$ & $2,91 \%$ \\
\hline
\end{tabular}

\subsection{Pengujian dan pengukuran pada pada Timbangan Manual atau} konvensional

Pada pengujian berat buah kali ini, menggunakan timbangan jenis manual atau konvensional dan dilakukan dengan cara memasukkan masing-masing buah apel, jeruk dan tomat kedalam timbangan konvensional. terdapat tiga timbangan konvensional, pada timbangan 1 diberi kapasitas pengukuran $3 \mathrm{Kg}$, timbangan 2 kapasitas pengukuran $4 \mathrm{Kg}$ dan timbangan yang 3 kapasitas pengukurannya $5 \mathrm{~kg}$. Hasil pengukuran berat buah menggunakan timbangan manual ini ditunjukkan pada Tabel 6,7,8 dan 9 di bawah ini.

Tabel 6. Hasil Pengujian dan Pengukuran Berat Buah Pada timbangan manual 1

\begin{tabular}{|c|c|c|c|c|c|}
\hline $\begin{array}{c}\mathbf{N} \\
\mathbf{0}\end{array}$ & Nama Buah & $\begin{array}{c}\text { Range } \\
\mathbf{( K g )}\end{array}$ & $\begin{array}{c}\text { Hasil Ukur } \\
\text { Timbangan } \\
\text { manual }\end{array}$ & $\begin{array}{c}\text { Rata-rata } \\
\text { Keberhasilan } \\
\text { pengukuran } \\
(\%)\end{array}$ & $\begin{array}{c}\text { Kesalahan } \\
\text { Pengukuran } \\
\text { Error } \\
(\%)\end{array}$ \\
\hline 1 & Apel & 3,0 & 2,9 & $96,66 \%$ & $3,44 \%$ \\
\hline 2 & Jeruk & 3,0 & 2,8 & $93,33 \%$ & $7,14 \%$ \\
\hline 3 & Tomat & 3,0 & 3,0 & $100 \%$ & $0 \%$ \\
\hline
\end{tabular}

Tabel 7. Hasil Pengujian dan Pengukuran Berat Buah Pada timbangan manual 2

\begin{tabular}{|c|c|c|c|c|c|}
\hline No & Nama Buah & $\begin{array}{c}\text { Range } \\
\mathbf{( K g )}\end{array}$ & $\begin{array}{c}\text { Hasil Ukur } \\
\text { Timbangan } \\
\text { manual }\end{array}$ & $\begin{array}{c}\text { Rata-rata } \\
\text { Keberhasilan } \\
\text { pengukuran } \\
\mathbf{( \% )}\end{array}$ & $\begin{array}{c}\text { Kesalahan } \\
\text { Pengukuran } \\
\text { Error } \\
(\%)\end{array}$ \\
\hline 1 & Apel & 2,0 & 2.0 & $100 \%$ & $0 \%$ \\
\hline 2 & Jeruk & 2,0 & 1,9 & $95,00 \%$ & $5,00 \%$ \\
\hline 3 & Tomat & 2,0 & 1,9 & $95,00 \%$ & $5,00 \%$ \\
\hline
\end{tabular}


Tabel 8. Hasil Pengujian dan Pengukuran Berat Buah Pada timbangan manual 3

\begin{tabular}{|c|c|c|c|c|c|}
\hline No & Nama Buah & $\begin{array}{c}\text { Range } \\
\mathbf{( K g )}\end{array}$ & $\begin{array}{c}\text { Hasil Ukur } \\
\text { Timbangan } \\
\text { manual }\end{array}$ & $\begin{array}{c}\text { Rata-rata } \\
\text { Keberhasilan } \\
\text { pengukuran } \\
(\%)\end{array}$ & $\begin{array}{c}\text { Kesalahan } \\
\text { Pengukuran } \\
\text { Error } \\
(\%)\end{array}$ \\
\hline 1 & Apel & 5,0 & 4,9 & $98,04 \%$ & $1,96 \%$ \\
\hline 2 & Jeruk & 5,0 & 4,8 & $96,00 \%$ & $4,16 \%$ \\
\hline 3 & Tomat & 5,0 & 5,0 & $100 \%$ & $0 \%$ \\
\hline
\end{tabular}

Tabel 9. Rata -rata Keberhasilan dan tingkat error pengukuran pada timbangan manual

\begin{tabular}{|c|c|c|c|c|c|}
\hline No & $\begin{array}{c}\text { Nama } \\
\text { Buah }\end{array}$ & $\begin{array}{c}\text { Jumlah } \\
\text { Range } \\
\mathbf{( K g )}\end{array}$ & $\begin{array}{c}\text { Jumlah Hasil } \\
\text { Ukur } \\
\text { Timbangan } \\
\text { manual (Kg) }\end{array}$ & $\begin{array}{c}\text { Jumlah Rata-rata } \\
\text { Keberhasilan } \\
\text { pengukuran } \\
\mathbf{( \% )}\end{array}$ & $\begin{array}{c}\text { Kesalahan } \\
\text { Pengukuran } \\
\text { Error } \\
\mathbf{( \% )}\end{array}$ \\
\hline 1 & Apel & 10,0 & 9,8 & $98,00 \%$ & $2,00 \%$ \\
\hline 2 & Jeruk & 10,0 & 9,5 & $95,00 \%$ & $5,00 \%$ \\
\hline 3 & Tomat & 10,0 & 9,9 & $99,00 \%$ & $1,00 \%$ \\
\hline
\end{tabular}

Berdasarkan hasil dan jumlah keseluruhan rata-rata yang didapatkan dari pengukuran dan pengujian berat buah menggunakan timbangan manual atau konvensional maka dapat dilihat perbedaan dan perbandingan antara hasil ukur load cell dan timbangan manual yang ditunjukkan pada data seperti pada Tabel 9 di bawah ini.

Tabel 10. Perbandingan Keberhasilan dan tingkat error pengukuran load cell dan timbangan manual

\begin{tabular}{|c|c|c|c|c|c|c|}
\hline No & $\begin{array}{c}\text { Nama } \\
\text { Buah }\end{array}$ & $\begin{array}{c}\text { Range } \\
\mathbf{( K g )}\end{array}$ & $\begin{array}{c}\text { Keberhasilan } \\
\text { pengukuran } \\
\text { Sensor Load } \\
\text { Cell (\%) }\end{array}$ & $\begin{array}{c}\text { Kesalahan } \\
\text { Pengukuran } \\
\text { Sensor Load Cell } \\
\mathbf{( \% )}\end{array}$ & $\begin{array}{c}\text { Keberhasilan } \\
\text { pengukuran } \\
\text { Timbangan } \\
\text { Manual (\%) }\end{array}$ & $\begin{array}{c}\text { Kesalahan } \\
\text { Pengukuran } \\
\text { Timbangan } \\
\text { Manual } \\
\text { (\%) }\end{array}$ \\
\hline 1 & Apel & 10,0 & $97,09 \%$ & $2,91 \%$ & $98,00 \%$ & $2,00 \%$ \\
\hline 2 & Jeruk & 10,0 & $99,00 \%$ & $1,00 \%$ & $95,00 \%$ & $5,00 \%$ \\
\hline 3 & Tomat & 10,0 & $97,09 \%$ & $2,91 \%$ & $99,00 \%$ & $1,00 \%$ \\
\hline & \multicolumn{2}{|c|}{ Total } & $97,73 \%$ & $2,27 \%$ & $97,34 \%$ & $2,64 \%$ \\
\hline
\end{tabular}


Untuk lebih jelas perbedaan dan perbandingan antara hasil ukur sensor load cell dan timbangan manual dapat dilihat pada grafik data Gambar 11 di bawah ini.

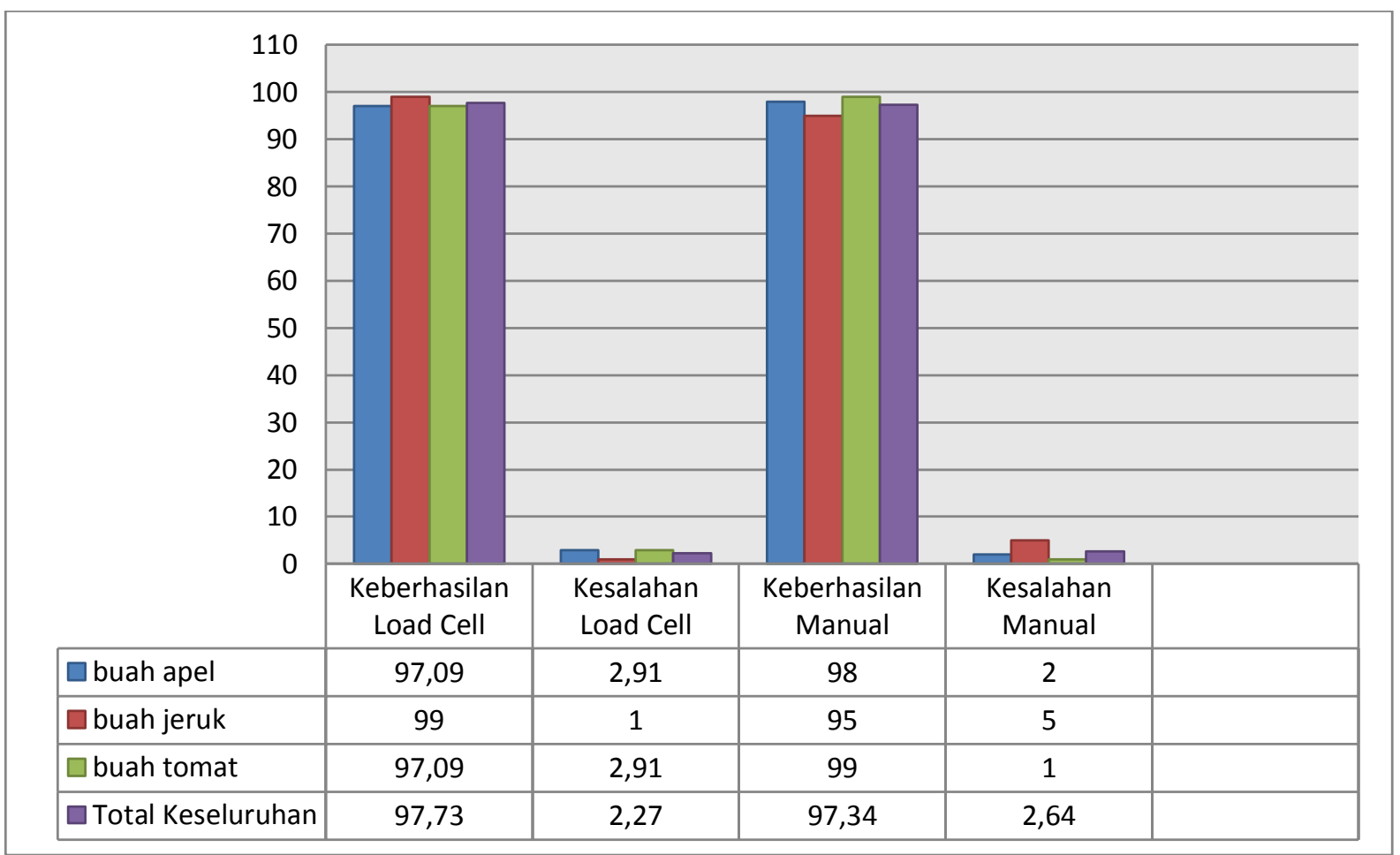

Gambar 11. Grafik data perbandingan pengukuran load cell dan timbangan manual

\subsection{Analisis Pengujian}

Hasil keseluruhan pengujian dan pengukuran menggunakan sensor load cell pada alat penyortir buah otomatis dan timbangan manual dilakukan dengan mengambil sampel perhitungan berat buah apel, jeruk dan tomat. Perhitungan berat buah menggunakan sensor load cell memakai tiga buah kotak timbang yang masing-masing kotak diberi kapasitas atau batas range pengukuran yang bervariasi. kotak pertama $3,5 \mathrm{~kg}$, kotak kedua $2,5 \mathrm{~kg}$ dan kotak ketiga $5 \mathrm{~kg}$, selanjutnya pengujian dilakukan sebanyak tiga kali agar bisa mendapatkan data pengukuran yang benar-benar akurat. Data yang didapat dari hasil pengkuran menggunakan sensor load cell yaitu data berupa tingkat keberhasilan pengukuran dan tingkat kesalahan pengukuran (error). Selanjutnya, untuk pengukuran dan pengujian pada timbangan manual atau konvensional, dilakukan dengan menggunakan tiga buah timbangan manual dengan batas range pengukuran yang berbeda-beda juga. untuk timbangan manual yang pertama diberi range pengukuran $3 \mathrm{~kg}$, untuk timbangan manual kedua diberi range pengukuran $2 \mathrm{~kg}$ dan pada timbangan manual ketiga diberi range pengukuran $5 \mathrm{~kg}$. Pengukuran hanya dilakukan satu kali saja. Dengan menganalisa data hasil pengujian yang disajikan pada Tabel 8 dan data grafik pada Gambar 11, maka diperoleh hasil perbandingan kinerja dari keduanya yaitu, tingkat keberhasilan pengukuran pada sensor load cell sebesar $97,73 \%$ dan tingkat kesalahan pengukurannya sebesar 2,27\%. Sedangkan Tingkat keberhasilan pengukuran pada timbangan manual atau konvensional 97,34\% dan tingkat kesalahan pengukurannya $2,64 \%$. 


\section{KESIMPULAN}

Pada penelitian kali ini yang berjudul perbandingan nilai ukur sensor load cell pada alat penyortir buah otomatis terhadap timbangan manual dan dapat disimpulkan bahwa pada penelitian kali ini hasi ukur sensor load cell ternyata lebih efisien dan akurat dalam melakukan pengukuran berat buah. Dengan hasil analisa data yang diperoleh dari hasil kinerja keduanya yaitu, tingkat keberhasilan pengukuran pada sensor load cell sebesar $97,73 \%$, dan tingkat kesalahan pengukurannya sebesar 2,27\%. Tingkat keberhasilan pengukuran pada timbangan manual atau konvensional $97,34 \%$ dan tingkat kesalahan pengukurannya $2,64 \%$. Jadi dapat disimpulkan bahwa pada penelitian kali ini hasil ukur sensor load cell ternyata lebih efisien dan akurat dalam melakukan pengukuran berat buah. Metode membandingan hasil ukur sensor load cell dengan timbangan manual merupakan salah satu cara yang efektif untuk mengetahui sejauh mana tingkat efisensi dan akurasi sistem kerja dari keduanya.

\section{DAFTAR RUJUKAN}

Thakkar, K.H., Prajapapti, V.M., \& Patel, B.D. (2013). Performance Evaluation of Strain Gauge Based Load Cell to Improve Weighing Accuracy. International Journal of Latest Trends in Engineering and Technology. 2(1) :103-107

Afdali, M. Daud., M. \& Raihan Putri. (2017). Perancangan Alat Ukur Digital untuk Tinggi dan Berat Badan dengan Output Suara berbasis Arduino UNO. Jurnal Elkomika. 5(1) :106 -118

Erlangga, W. B. (2011). Rancang Bangun Timbangan Digital Dengan Pemilihan Jenis Buah. Tugas Akhir. Universitas Negeri Malang.

Hidayani, T.U., T.Maharani \& Abdul Rahman. (2013). Rancang Bangun Timbangan Buah Digital Dengan Keluaran Berat dan Harga. Jurnal eprints mdp. 917(1):1-10.

Kamirul., H. Syahwanti., A. Nelvi \& M.S. Hendro. (2015). Rancang Bangun Data Logger Massa Menggunakan Load Cell. Prosiding Seminar Kontribusi Fisika (pp. 211-214).

Khakim, A. L. (2015). Rancang Bangun Alat Timbang Digital Berbasis AVR Tipe Atmega32. Tugas Akhir. Semarang: Universitas Negeri Semarang.

Nuryanto, R. (2015). Pengukur Berat dan Tinggi Badan Ideal Berbasis Arduino. Karya IImiah Program Sarjana. Surakarta: Universitas Muhammadiyah Surakarta.

Latifa, Siti. (2014). Mengoprasikan Alat Ukur. Dipetik pada 15 Mei 2017 dari http://latifah0307.blogspot.com/2014/03/mengoperasikan-alatukur.html 